УДК 371.132

DOI: 10.37026/2520-6427-2020-103-3-89-93
Наталя КОШЕЛЕВА,

кандидат педагогічних наук, дочент,

дочент кафедри психології

Горлівського інституту іноземних мов

ДВНЗ «Донбаський державний педагогічний університет»,

м. Бахмут Донеиької області

\title{
РОЗРОБЛЕННЯ МОДЕЛІ МЕТОДИЧНОЇ КОМПЕТЕНТНОСТІ МАЙБУТНІХ ВИКЛАДАЧІВ ПСИХОЛОГІЇ
}

У статті окреслено проблему формування методичної компетентності майбутніх викладачів психології. Сформульовано пропозицї̈ щзодо зміни змісту $i$ форм їхньої методичної підготовки на основі компетентнісного підходу. Обгрунтовано необхідність розробки моделі методичної компетентності майбутніх викладачів психології як теоретичної основи прочесу ї̈ формування. Визначено компоненти представленої моделі та схарактеризовано їхній зміст. Доведено ефективність використання засобів дидактичного проєктуванняз метою формування досліджуванойкомпетентності. Запропоновано використовувати магістрантами розробку дидактичних проєктів з підготовки бакалаврів-психологів та здійснювати їхню апробачію під час педагогічної практики. Даний підхід дозволяє забезпечити наявність досвіду методичноі діяльності в майбутніх викладачів психології $і$ сприяє формуванню їхньої методичної компетентності.

Ключові слова: компетентнісний підхід, модель методичної компетентності, методична підготов$к а$, методична діяльність, дидактичне проєктування, майбутні викладачі психології.

В статье обозначена проблема формирования методической компетентности будущих преподавателей психологии. Сформулировань предложения по изменению содержания и форм их методической подготовки на основе компетентностного подхода. Обоснована необходимость разработки модели методической компетентности будущих преподавателей психологии как теоретической основы проиесса ее формирования. Определены компоненты представленной модели и охарактеризовано их содержание. Доказана эффективность использования средств дидактического проектирования с иелью формирования исследуемой компетентности. Предложено использовать магистрантами разработку дидактических проектов подготовки бакалавров-психологов и осуществлять их апробацию во время педагогической практики. Данный подход позволяет обеспечить наличие опыта методической деятельности у будущих преподавателей психологии и способствует формированию их методической компетентности.

Ключевые слова: компетентностный подход, модель методической компетентности, методическая подготовка, методическая деятельность, дидактическое проектирование, будущие преподаватели психологии.
The article discusses the actual problem of methodological competence formation of future psychology teachers in the learning process. A number of scientific studies devoted to the implementation of the competence-based approach in education and the definitions of its basic concepts are analyzed. It has been determined that an important part of a teacher's professional competence is a methodological component. The difficulties and contradictions of the process of forming the methodological competence of future psychology teachers are revealed. It is noted that they are associated with the predominance of the traditional approach to the methodological training of undergraduates of specialty 053 «Psychology». It has been determined that the formation of the studied competence requires practical experience of methodological activity among future psychology teachers. A proposal is formulated to change the content and forms of their methodological training based on the competence-based approach. The necessity of developing a methodological competence model of future psychology teachers as a theoretical basis for the process of its formation is substantiated. The development of the model is based on the ideas of the stage-by-stage formation of mental actions theory, developed by P.Ya. Halperin. The components of the methodological competence model of future psychology teachers are determined: motivational, cognitive, operational and control-corrective. Their detailed content has been developed, allowing to determine the goals and directions of the methodological training of undergraduates. The effectiveness of the use of didactic design tools for the formation of the studied competence is noted. It is proposed to focus on the project form of undergraduates' work in the discipline "Methods of teaching psychology in higher education", which involves the development of didactic projects for training bachelors-psychologists. The developed projects are proposed to be tested during teaching practice. This approach allows future psychology teachers to have experience in methodological activity and contributes to the formation of their methodological competence.

Key words: competence-based approach, methodological competence model, methodical preparation, methodical activity, didactic design, future psychology teachers. 
Постановка проблеми. Система вищої педагогічної освіти України на сучасному етапі зазнає суттєвих змін і перетворень, зокрема на основі компетентнісного підходу. У Законі України «Про освіту» зазначено, що «держава створює умови для здобуття громадянської освіти, спрямованої на формування компетентностей, пов'язаних із реалізацією особою своїх прав і обов'язків» [5]. Із цього положення логічно випливає вимога щодо високого рівня сформованості професійної компетентності вчителів та викладачів, які здійснюють педагогічний процес у закладах освіти всіх рівнів. Її важливою складовою $€$ методична компетентність, яка «включає засвоєння педагогом нових методичних і педагогічних ідей, підходів до навчально-виховного процесу в сучасних особистісно орієнтованих, розвивальних, креативних технологіях, володіння різними методами, прийомами і формами організації навчання» [9, с. 177].

Проте власний багаторічний досвід діяльності в педагогічних закладах вищої освіти (далі - 3BO), аналіз результатів проходження студентами педагогічних практик, вивчення наукового доробку інших дослідників із проблем формування методичної компетентності майбутніх викладачів свідчать про наявність проблем у цій сфері. Так, аналізуючи процес і результати вивчення магістрантами спеціальності 053 «Психологія» дисципліни «Методика викладання психології» та проходження ними педагогічної (асистентської) практики, можна дійти висновку про теоретичний характер отриманих студентами знань із методики, невміння кваліфіковано застосувати їх на практиці та наявність численних проблем, пов'язаних із підготовкою та проведенням реальних занять у бакалаврів-психологів. Відповідно традиційний підхід до засвоєння зазначених складових навчального плану має бути змінений (і це має відбуватися в рамках саме компетентнісного підходу, оскільки «інтеграція у змісті освіти понять, способів людської діяльності, творчого потенціалу, досвіду прояву особистісної позиції відбувається у процесі створення здобувачами освіти на основі означених вище видів власного досвіду» [1, с. 11]. Формування методичної компетентності майбутнього викладача передусім має базуватися на науково обгрунтованій основі, мати чітку практичну орієнтацію і бути реалізованою ще в процесі підготовки у ЗВО, де майбутній викладач психології отримає свій перший досвід упорядкованої та планомірної методичної діяльності. По-іншому, зміст методичної підготовки майбутніх викладачів психології має передбачати формування власного досвіду системного виконання типових завдань методичної діяльності викладача 3ВО, а не лише зводитися до вивчення педагогічних понять і категорій, а також епізодичної підготовки до навчальних занять під час практики.

Аналіз наукових досліджень і публікацій. Особливості реалізації компетентнісного підходу в освіті активно розробляються провідними вітчизняними та зарубіжними вченими. Сутність компетентнісного підходу, який досліджували А. Вербицький, О. Глузман, Е. Зеєр, І. Зимня, О. Овчарук, О. Пометун, І. Родигіна, Г. Селевко, В. Сєріков А. Хуторський та інші науковці, полягає у перенесенні акцентів у постановці освітніх цілей із отримання здобувачами освіти знань на формування здатності ефективно діяти в різних ситуаціях на основі знань, здібностей, досвіду тощо. Якщо особливістю компетентнісного підходу, за I. Родигіною, $є$ нова мета навчання, очевидним стає те, що відповідно до неї мають бути адаптовані всі компоненти освітнього процесу [6] - зміст, методи, форми, засоби, результати навчання, функції викладачів та здобувачів освіти. Зважаючи на це, вимога щодо високого рівня сформованості методичної компетентності викладача виходить на перший план і має бути забезпечена змінами у його підготовці у ЗВО.

Компетентність як одне з ключових понять компетентнісного підходу є предметом досліджень Н. Бібік, В. Болотова, В. Галузяка, М. Голованя, Н. Кузьміної, В. Лозової, А. Маркової, С. Савельєвої, В. Стрельнікова, Ю. Татура, С. Шишова та ін. Так, Ю. Татур визначає компетентність фахівця як «виявлені ним на практиці прагнення і здатність (готовність) реалізувати власний потенціал (знання, вміння, досвід, особистісні якості тощо) для майбутньої успішної творчої (продуктивної) діяльності у професійній та соціальній сферах» [7, с. 9], а В. Сєріков і В. Болотов як «складний синтез когнітивного, предметно-практичного й особистісного досвіду» $[1$, с. 12].

Сутність та особливості формування педагогічної компетентності висвітлено в науковому доробку В. Адольфа, Л. Ващенко, В. Введенського, С. Вітвицької, І. Зязюна, Л. Карпової, Н. Ничкало, С. Сисоєвої, О. Семеног та ін. Зокрема, заслуговує на увагу визначення, окреслене О. Фесенко: «Пропонуємо розглядати професійну компетентність педагога як здатність ефективно розв'язувати стандартні та проблемні ситуації, що виникають у педагогічній діяльності за рахунок єдності теоретичної й практичної готовності педагога до здійснення педагогічної діяльності» $[8$, с. 131].

Більшість дослідників виокремлюють у складі професійно-педагогічної компетентності методичну складову. Дослідженню останньої присвячено наукові праці Т. Гущиної, Г. Грищенка, В. Заболотного, А. Зубкова, А. Кузьминського, О. Лебєдєвої, Т. Руденко, С. Скворцової, К. Ткаченко та ін. На думку О. Ніколаєва та Л. Рубаняк, «методична компетентність передбачає знання в галузі дидактики, методики навчання дисципліни, вміння логічно й обгрунтовано конструювати навчальний процес для конкретної дидактичної ситуації з урахуванням психологічних механізмів засвоєння навчального матеріалу» [4, с. 99].

Незважаючи на значну кількість досліджень, проблема науково обгрунтованого формування методичної компетентності майбутніх викладачів психології поки не знайшла достатнього висвітлення в науковій літературі, що й обумовило спрямованість нашого дослідження.

Метою статті $є$ розробка й обгрунтування моделі методичної компетентності майбутніх викладачів психології у процесі підготовки у ЗВО.

Виклад основного матеріалу. У сучасній педагогічній теорії прийнята точка зору, за якою моделювання складних процесів фахової підготовки і професійної діяльності фахівців $є$ умовою і способом їхнього ефективного вдосконалення. Під моделлю розуміється система, що відображає об'єкт вивчення і може заміщати його при дослідженні з метою отримання 
нової інформації про нього, його властивості та поведінку в певних умовах [10]. Отже, для наукового обгрунтування процесу формування методичної компетентності майбутніх викладачів психології необхідно розробити їі модель.

Оскільки, як було відзначено вище, компетентність фахівця виявляється у його здатності ефективно діяти в різних ситуаціях, вважаємо, що при розробці моделі досліджуваної компетентності логічно виходити 3 етапів формування діяльності, визначених у теорії поетапного формування розумових дій, розробленій П. Гальперіним. Основними етапами формування діяльності у ній виокремлено такі: формування мотивації засвоєння та здійснення дії; забезпечення орієнтовної основи для виконання дії; формування виконавчої дії з усіма необхідними якостями; перенесення дії в розумовий план [2, с. 18]. Візьмемо ці етапи за основу для визначення компонентів моделі досліджуваної нами компетентності. Послідовна реалізація цих етапів у процесі методичної підготовки магістрантів, а отже, і формування відповідних до них компонентів досліджуваної компетентності, забезпечить здатність майбутніх викладачів психології усвідомлено, повноцінно та ефективно здійснювати методичну діяльність. Таким чином, включимо до моделі методичної компетентності майбутніх викладачів психології компоненти, представлені нижче (див. рис.).

Загальна модель методичної компетентності майбутніх викладачів психології

\begin{tabular}{|c|c|c|c|}
\hline$\nabla$ & 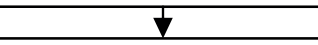 & $\nabla$ & $\nabla$ \\
\hline Мотиваційний & Когнітивний & Операційний & Контрольно- \\
\hline компонент & компонент & компонент & корекційний \\
\hline забезпечує & забезпечує & забезпечує & компонент \\
\hline усвідомлення & засвоєння & формування & забезпечує кореляцію \\
\hline цілей методичної & і творче & практичних умінь & всіх інших \\
\hline діяльності, & осмислення & виконувати всі & компонентів, контроль \\
\hline прагнення до & інформації та & види методичної & за ходом виконання \\
\hline 1̈і якісного & знань, необхідних & діяльності & дії, зіставлення \\
\hline здійснення, & для здійснення & та здатність їх & отриманих результатів \\
\hline потребу в & методичної & застосовувати в & iз поставленими \\
\hline підвищенні & діяльності & різних ситуаціях i & цілями, аналіз якості \\
\hline власного рівня & & до різних завдань & здійсненої методичної \\
\hline методичної & & методичної & діяльності та \\
\hline компетентності & & діяльності & необхідну корекцію \\
\hline
\end{tabular}

Рис. Модель методичної компетентності майбутніх викладачів психологї

Докладніше зміст запропонованих компонентів представлено нами в таблиці. При визначенні змісту когнітивного та операційного компонентів було використано підхід, запропонований О. Коваленко [3], в основу якого покладено застосування засобів дидактичного проєктування у процесі методичної підготовки майбутніх викладачів.

Таблиия

Зміст компонентів моделі методичної компетентності майбутніх викладачів психології

\begin{tabular}{|l|l|}
\hline $\begin{array}{c}\text { Компоненти } \\
\text { методичної } \\
\text { компетентності }\end{array}$ & \multicolumn{1}{|c|}{ 3міст компонентів методичної компетентності } \\
\hline Мотиваційний & - інтерес до методичної діяльності в цілому та їі різновидів; \\
- інтерес до ознайомлення з досвідом методичної діяльності інших викладачів; \\
- бажання опанувати сучасними методиками і технологіями навчання із психологічних \\
дисциплін, новітніми й оригінальними прийомами методичної діяльності; \\
- потреба у створенні власних якісних методичних розробок, авторських методик і техно- \\
логій навчання із психологічних дисциплін з оптимальним вибором дидактичних методів, \\
форм і засобів; \\
- прагнення якісно та ефективно проводити навчальні заняття із психологічних дисциплін, \\
використовуючи власні методичні розробки; \\
- бажання якнайповніше реалізувати власні методичні здібності для досягнення високих \\
результатів педагогічної діяльності; \\
- бажання вдосконалювати власні методичні знання та вміння засобами самоосвіти, під- \\
вищення кваліфікації тощо.
\end{tabular}


Продовження таблищі

\begin{tabular}{|c|c|}
\hline $\begin{array}{l}\text { Компоненти } \\
\text { методичної } \\
\text { компетентності }\end{array}$ & Зміст компонентів методичної компетентності \\
\hline Когнітивний & $\begin{array}{l}\text { Знання: } \\
\text { - педагогічної теорії в цілому, їі основних законів, понять і категорій; } \\
\text { - цілей, змісту і видів методичної діяльності викладача ЗВО; } \\
\text { - видів методичних розробок у ЗВО та вимог до них; } \\
\text { - сутності та структури дидактичного проєктування як процесу розробки проєктів підго- } \\
\text { товки майбутніх фахівців; } \\
\text { - методики аналізу професійної діяльності фахівців і конструювання змісту освіти; } \\
\text { - методики аналізу та прогнозування мети навчання; } \\
\text { - методики аналізу й діагностики стану навчального процесу; } \\
\text { - методики проєктування дидактичних матеріалів; } \\
\text { - методики вибору технологій навчання і контролю; } \\
\text { - методики планування та організації навчального процесу; } \\
\text { - психологічних механізмів і закономірностей реалізації педагогічного процесу. }\end{array}$ \\
\hline One & 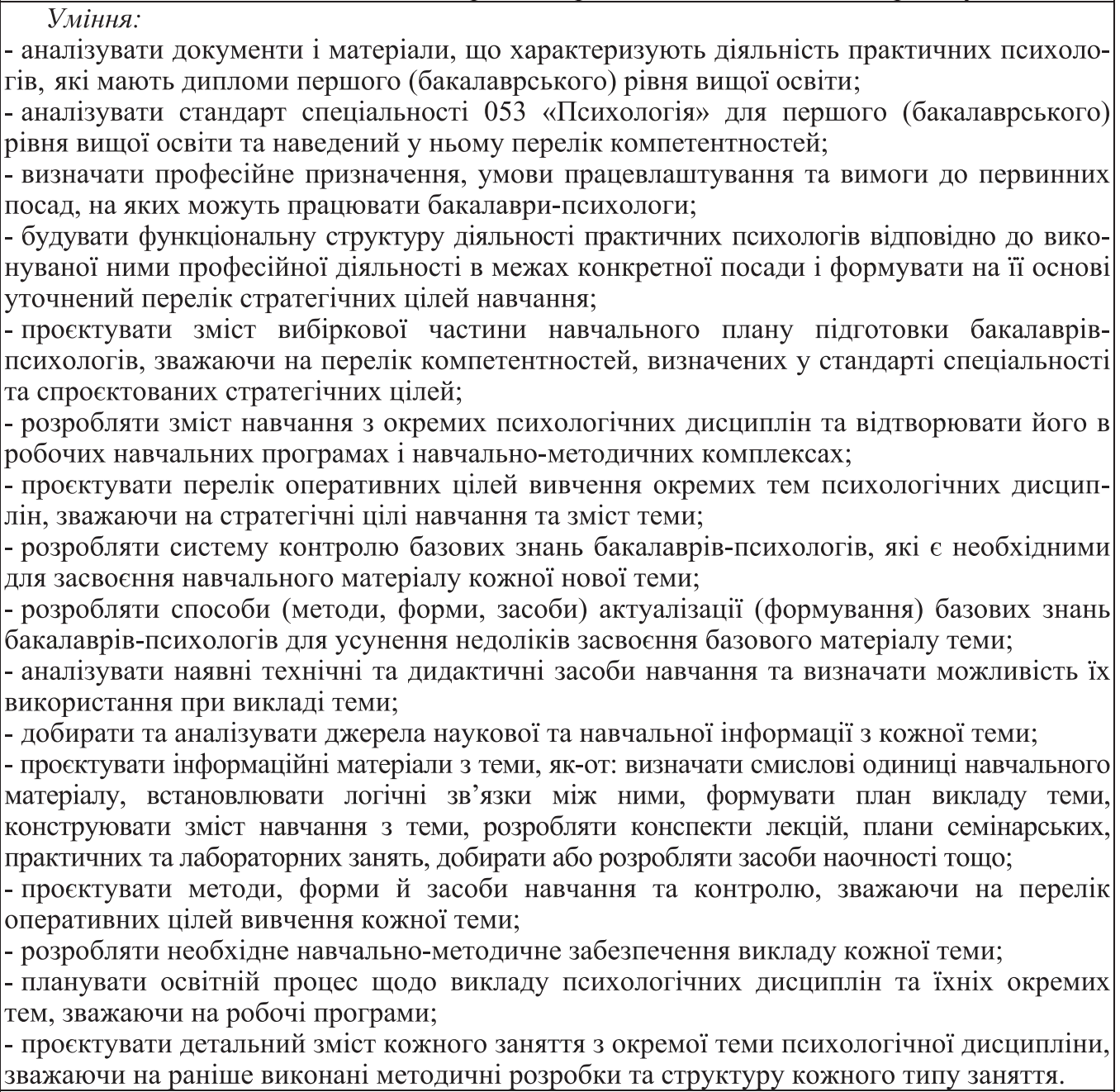 \\
\hline $\begin{array}{l}\text { Контрол } \\
\text { корекціi }\end{array}$ & $\begin{array}{l}\text { 3датність і вміння аналізувати кожен етап виконаної методичної діяльності, порівнювати } \\
\text { ïx із цілями й вимогами, визначати напрями і способи вдосконалення результатів власної } \\
\text { методичної діяльності та відповідним чином коригувати підготовлені матеріали й розробки. }\end{array}$ \\
\hline
\end{tabular}

Таким чином, для успішної реалізації всіх компонентів розробленої нами моделі необхідно переглянути традиційний підхід до викладання дисципліни «Методика викладання психології у вищій школі» в процесі підготовки магістрантів спеціальності 053 «Психологія» у ЗВО та проходження ними педагогічної (асистентської) практики. У зв'язку з цим пропонуємо зробити акцент на проєктній формі роботи
3 означеної вище дисципліни, коли майбутні викладачі психології зможуть спробувати свої сили у розробці дидактичних проєктів 3 підготовки бакалаврів-психологів. За такої умови варто застосовувати групові форми роботи з розподілом індивідуальних завдань та обов'язковим подальшим спільним аналізом і коригуванням. Порядок розробки дидактичних проєктів підготовки бакалаврів-психологів може бути таким: 
розробка проєкту навчання зі спеціальності (аналіз діяльності фахівця; розробка змісту професійної підготовки фахівця); розробка проєкту навчання з дисципліни чи теми (діагностика мети у процесі навчання; діагностика стану навчання; підготовка інформаційних матеріалів; добір навчальної літератури; розробка технологій навчання та контролю; планування освітнього процесу) [3, с. 37]. Отримання магістрантами заліку з дисципліни має відбуватися за результатами захисту розроблених дидактичних проєктів, а їхнє впровадження в реальний педагогічний процес підготовки бакалаврів-психологів повинно бути обов'язковою вимогою до проходження педагогічної (асистентської) практики (з відображенням та аналізом результатів у звітах із практики).

Висновки. Отже, нами було розроблено й обгрунтовано модель методичної компетентності майбутніх викладачів психології у процесі підготовки у ЗВО, реалізація якої має відбуватися на засадах компетентнісного підходу засобами дидактичного проєктування. Побудова методичної підготовки майбутніх викладачів психології на основі даної моделі забезпечить формування в магістрантів власного досвіду системного виконання типових завдань методичної діяльності викладача ЗВО і сприятиме становленню їхньої методичної компетентності у процесі навчання.

Подальші дослідження плануємо присвятити обгрунтуванню та розробці педагогічних умов формування методичної компетентності майбутніх викладачів психології у процесі підготовки у ЗВО на основі розробленої моделі.

\section{СПИСОК ВИКОРИСТАНОЇ ЛІТЕРАТУРИ}

1. Болотов В. А., Сериков В.В. Компетентностная модель: от идеи к образовательной программе. Педагогика. 2003. № 10. С. 8-14.
2. Гальперин П.Я. Введение в психологию. Москва : Книжный дом «Университет», 2006. 327 с.

3. Коваленко О. Е., Брюханова Н. О., Корольова Н. В., Шматков С. В. Методика професійного навчання. Харків : ВПП «Контраст», 2008. 488 с.

4. Ніколаєв О. М., Рубаняк Л. А. Методична компетентність як одна із основних складових професіоналізму майбутнього вчителя фізики. Збірник наукових праць Кам'янець-Подільського національного університету ім. Івана Огієнка. Серія «Педагогічна». 2016. Вип. 22. С. 99-102.

5. Про освіту : Закон України від 05 верес. 2017 р. № 2145-VIII. URL: https://zakon.rada.gov.ua/laws/show/ 2145-19\#Техt (дата звернення: 23.07.2020).

6. Родигіна I. Компетентнісно спрямований педагогічний процес. URL: http://osvita.ua/school/ theory/1963 (дата звернення: 23.07.2020).

7. Татур Ю. Г. Компетентностный подход в описании результатов и проектировании стандартов высшего профессионального образования. Материаль ко второму заседанию методологического семинара: авторская версия. Москва : Исследовательский центр проблем качества подготовки специалистов, 2004. $16 \mathrm{c}$.

8. Фесенко О. С. Дослідження феномена «професійна компетентність» вчителя у науковій літературі. Вісник Черкаського університету. Серія «Педагогічні науки». 2015. Вип. № 32 (365). С. 128-133.

9. Ціпан Т. С. Професійна компетентність сучасного вчителя. Інноватика у вихованні. Рівне, 2016. Вип. 3. С. 174-181.

10. Якубовски М. А. Математическое моделирование профессиональной деятельности учителя : монография. Львов : Евросвит, 2003. С. 102-105.

Дата надходження до редакиї: 26.07.2020 p.

Ярослав СЛУЦьКИй, кандидат педагогічних наук, завідувач навчально-методичним кабінетом Донбаського державного коледжу технологій та управління, м. Торецьк Донецької області

\section{ЗАГАЛЬНІ ВИМОГИ ДО ОСВІТНЬОЇ ПРОГРАМИ СОЦАЛЬНО-ПЕДАГОГІЧНОГО СУПРОВОДУ ІНОЗЕМНИХ СТУДЕНТІВ}

У статті розглянуто основні вимоги до освітньої програми, щчо використовується при проведенні адаптаційних заходів з іноземними студентами. У ході здійсненого дослідження надано характеристику фундаментальним положенням, наявність яких є важливою умовою для створення програми сочіально-педагогічного супроводу, як-от: необхідність формування в іноземних студентів відповідних теоретичних знань та практичного досвіду для можливості вирішення сочіальних і академічних проблем, щзо виникають при акультуращії; базування теоретичного комплексу програми на основі реальних практичних проблем, які в повсякденній діяльності іноземного студента стають перешкодою для соиіалізаціі; використання в основі програми сочіальнокультурних матеріалів, які сприяють ознайомленню 